was aware of the apparent exceptions signalized by Mr. Dall, and could add extinct forms referred to the Pteriidae or Aviculidae, as well as the Muelleriidae retained among the Dimyaria. The Monomyaria seemed to me, however, to be a natural 'genetic' group, and the Muelleriidae were bimusculose in youth, and their monomyarian characteristics in the adult appeared to be a peculiar teleological adaptation. I am still disposed to believe that the Monomyaria constitute a natural group, although Mr. Dall has good reasons for thinking that, "in fact, there does not at present seem to be any good basis for ordinal divisions in the Lipocephala." What Mr. Dall designates as 'the remarkable characters of the group of Metarrhiptae' seemed to me to furnish as good a basis for an 'order' as any of those that have been used for that purpose: consequently I gave the name as an ordinal designation in 1871.

But the question whether certain groups are of ordinal or minor value is of less moment than the natural subdivision of the class. If the myological peculiarities are not the best criteria, what are?

A view that has had some currency, that the Monomyaria are inferior forms of Acephala, is negatived by both embryological and paleontological evidence. The testimony of both is conclusive that the Monomyaria are derivatives from Dimyaria.

Is it certain that the shell of the Polyplacophora (Chitons) is the exact homologue of the shells of the typical Gastropods? I am acquainted with what has been published of the embryology of the group, but am left in doubt both as to facts and interpretations. At any rate, it is certain that the old views of a close relation between the Polyplacophora and the docoglossate Gastropoda had very little morphological basis.

My gratitude for the excellent article of Professor Lankester impels me to cordially indorse the encomiums of Mr. Dall, while I concur with the critic as to the family arrangement.

Professor Lankester has sometimes been misled, too, by not remembering that the same objects may be called by different names : for instance, he has referred to the 'Rachiglossa (1.1.1, or 1)', a gastropod named 'Pyrula, Lam. (fig. 38),' but the figure represents a type belonging to the "Tenioglossa (3. 1. 3), and repeated thereunder as one of the 'family 4, Doliidæ,' under the name 'Ficula.' As my eyes light on neighboring names, I may add that the 'Pediculariidae' and 'Ovulum' do not fulfil the conditions of the 'Siphonochlamyda,''shell always spiral:' they do not have true spires. Professor Lankester has been deceived by false guides. Such lapses are, however, of a kind inevitable in a general work; for it is impossible for one man to verify every statement. Theo. GiLL.

\section{A fasting pig.}

Is a recent flood (June 26) that visited this neighborhood, Mr. John Aughenbaugh of West Manchester township had five hogs carried away by the water. On Aug. 7 one of them was found under a large heap of driftwood about a mile from the home of Mr. Aughenbaugh. The animal had been securely imprisoned by the timber, and had not eaten any thing for forty-two days. Although very considerably emaciated when released from its prison, it appeared to have no trouble in emptying a crock of thick milk that was offered it. It has since been doing well, and no doubt will soon recover all it lost in flesh.

E. F. S.

York, Penn.

\section{A WIDER USE FOR THE LIBRARIES OF SCIENTIFIC SOCIETIES.}

To those who are obliged to use the libraries of our smaller colleges, it is often a source of vexation to find that the books one is referred to are wanting. The resources of the colleges are limited, and the amount of money which can be expended for the purchase of new books small, and that small amount often deroted, according to the wishes of the donor, to the class of books least needed. A case in point occurred lately, where a college professor of mathematics was asked to write a short account of the life of Todhunter; and he felt obliged to say that he would be glad to undertake the article, but could not before he had visited the libraries of either New York or Boston, which he hoped to be able to do during his next vacation.

This constant lacking of just the books one needs for his work is most hampering. It is not the Century, or the Harper, or the latest novel, or the new book of travel, which cannot be had (these find their way into all the odd corners), but it is the specialist's books, a volume of the transactions of some learned society, a scientific journal, or the modern treatises on thermo-dynamics, on electricity, or on biology, which are needed, and which can be found only in a very few of our libraries in the necessary profusion.

A few such libraries have now been collected by our older scientific societies and our larger colleges. The books of the college libraries are for a specific purpose, and find abundant use at the hands of the students and professors. With the societies the matter stands differently. It cannot be denied that one of the original objects of the establishment of these societies was, that, by the publication of their own ' proceedings,' they might, by exchange, gather a collection of books which could not, in the then comparatively poor state of the country, be gathered in any other way, and which were to be for the use of the members, and such favored friends as they might designate.

It has so happened that these societies were established by the small knots of scientific 